This is a pre-copyedited, author-produced PDF of an article accepted for publication in RIVISTA ITALIANA DI SCIENZA DELLA POLITICA following peer review. The version of record [Bordandini, P., \& Mulé, R. (2018). Attitudes and opinions of Italian middle-level elites in the new millennium. Adaptation, innovation, or persistence? Italian Political Science Review/Rivista Italiana Di Scienza Politica, 48(1), 23-42. doi:10.1017/ipo.2017.14] is available online at:https://www.cambridge.org/core/journals/italian-political-science-reviewrivista-italiana-di-scienza-politica

\title{
Attitudes and Opinions of Italian Middle-Level Elites in the New Millennium. Adaptation, Innovation or Persistence?
}

\begin{abstract}
The literature on party politics has generally conceived of party change as party adaptation. Building on the theories of institutional change based on critical juncture analysis, our work contributes to the literature in two ways. Theoretically, by unpacking the concept of party change in three dimensions: adaptation, innovation and persistence. This multidimensionality has been unduly neglected in the literature, too exclusively focused on party adaptation. Empirically, the article analyses whether the attitudes and opinions of middle-level elites reveal adaptation, innovation or persistence in their belief system at the beginning of the third millennium. Drawing upon a unique dataset of national party delegates of
\end{abstract}


15 Italian political parties, regression results suggest that high entry barriers in party organizations may hinder Schumpeterian innovation.

Keywords: party change, adaptation, innovation, party middle-level elite, belief system

\section{Introduction}

The topic of party change has been a popular theme in the party politics literature in the last twenty years (Bardi, Bartolini and Trechsel 2014, Bosco and Morlino 2006, Harmel and Janda 1994, Katz and Mair 1995, Raniolo 2002 and 2013). Many interpretations of party change draw on theories of institutional change because political parties are first and foremost complex institutions (Michels 1951, Panebianco 1988, Katz and Mair 1992). These interpretations suggest that party change may be evolutionary or developmental, continuous or discontinuous; it may be a gradual process of stimuli-response to environmental challenges, internal pressures or a combination of both. 
Following this line of research, our paper draws on recent advances in the theory of institutional change ${ }^{1}$ to examine if and in what manner middle level elites perceive party transformations. The new wave of research contends that institutions may or may not respond to external stimuli because of the resilience and stickiness of institutional patterns. In consequence, change in political environments may be associated with persistence rather than adaptation or innovation. ${ }^{2}$ Building on this new research programme, we argue that party change is a multidimensional process, characterized by adaptation, innovation or persistence.

It should be noted that we are not interested in party change as such but in the way in which party national delegates perceive change. Our research question is whether the critical juncture caused by the Italian political turmoil during the 1990s has been matched by adaptation, innovation or persistence in Italian middle level elites' attitudes and opinions. Our empirical analysis is based on interviews of middle-level elites of 15 Italian political parties collected between 2004 and 2013. The article chiefly focuses on the first decade of the new

\footnotetext{
${ }^{1}$ In particular, we refer to the recent work of Mahoney and Thelen ( 2015) and Capoccia (2015).

${ }^{2}$ As Lanzara (2016) argues, the old world generates incentives and pressures to conservation that make the status quo hard to be relinquished. At times the process of innovation starts but never reaches stability and consolidation because it is swallowed up by the old system.
} 
millennium because this is a crucial period in Italian politics. In this period new party alignments shaped the pre-conditions that led to the 'electoral earthquake' of 2013 (Chiaramonte and De Sio 2014). This analysis is then updated and integrated with findings of a recent survey carried out during the Partito Democratico national conference held in Milan in 2013.

Our research builds upon previous work on Italian national party delegates (Di Virgilio and Giannetti, Bordandini, et al 2011, Bordandini 2012; Cerruto and Facello 2014). It improves on extant literature by offering an analytical framework based on advances in theories of institutional of change and by testing the expectations derived from these theories. The article is structured as follows. Section two outlines our theoretical framework. Section three analyses whether the Italian political turmoil of the 1990s can be considered a critical juncture. The fourth section describes the unit of analysis and the available dataset. Section five explores the belief system of middle-level elites. The sixth develops a statistical model to assess the relationship between innovation and barriers to entry in party organizations. The next session updates the dataset in order to assess whether our results hold on a sample of party delegates at the 2013 national conference of the Partito Democratico. The last section offers some concluding remarks. 


\section{The theoretical framework}

Peter Mair, one of the most accomplished scholars in the field of party change ${ }^{3}$, believes that the focus on party change rests primarily on how this question can be approached and interpreted (1997, viii). Thus, the first cut into the problem of party change is to clarify the meaning of the term 'change'. In Mair's view, the meaning of the term 'change' is derived from its opposite: persistence or stability. Detecting persistence of organisational and behavioural traits in political parties denotes stability on those traits. Party change is the opposite of changeless or immutable conditions.

When socio-economic conditions do vary, the traditional literature on party politics emphasises party adaptability to those variations. This approach has spawned a wide literature on party change based on adaptation as the party's chief resource ((Bardi, Bartolini and Trechsel 2014; Calise 2010).

Interpreting party responses as adaptation to environmental pressures is an important building block of research on party change. As mentioned above, this research draws on the theories of institutional change based on exogenous factors as triggers of party change.

Our work updates this tradition by applying the recent theory of institutional change concerned with critical junctures. Critical junctures are defined as

\footnotetext{
${ }^{3}$ See the special issue of Party Politics (2014) written in honour of Peter Mair.
} 
'moments in which uncertainty as to the future of an institutional arrangement allows for political agency and choice to play a decisive causal role in setting an institution on a certain path of development' (Capoccia 2015, 148). Critical junctures induce discontinuous and radical reorganization because of an in-built capacity to overcome institutional stasis. In this view, institutional change results from a breakdown of traditional and continuous dynamics in the organization, bringing about innovative patterns and configurations. Critical junctures generate uncertainty by disrupting the institutional status quo. In times of uncertainty, when multiple options are available to key actors, the expectation is that the organisational scenario of politics creates space for political entrepreneurship and innovation (Capoccia 2015, 160).

We contend that this perspective is important for understanding party change because it suggests that critical junctures may induce innovation and not-merely adaptation. The distinction between adaptation and innovation is noteworthy. Innovation brings about new ideas, practices, procedures and programmes; it is unprecedented and it is always qualitative in nature. Lowi $(1963,581-582)$ claims that innovation helps the formulation of problem solving policies apt to meet political challenges and therefore is a continuing requirement of a free and dynamic society. This is why the analytical distinction between party change as 
adaptation or innovation is relevant for political scientists. Yet research findings on party innovation are few and far between (Appleton and Ward 1997).

A further point to note is that in democracies parties are channels of innovation only if they are able to represent social diversity. Franzman $(2011,339)$ considers heterogeneity of political competitors a necessary condition for innovation. If parties are too homogenous, in the sense that they do not sufficiently represent voters' diversity, the emergence of new parties promising innovation is likely. But what is the meaning of innovation? We adopt Schumpeter's definition of innovation as 'creative destruction', a process of mutation that destroys the old and creates new ones (Schumpeter 1934). Empirically, this is not mere substitution; rather the shaping of previously unknown models, ideas, configurations or arrangements by political entrepreneurs or 'leaders-new people'. In a nutshell, innovation is change caused by endogenous forces, while adaptation is change induced exclusively from exogenous forces. Surely, endogenous forces at times latch on exogenous pressures to foster innovation. A typical example is when a political entrepreneur confronts environmental challenges. In this case endogenous and exogenous forces intermingle. In general, however, innovation always entails the substitution of the old with the new through a process of Schumpeterian 'creative destruction'. Adaptation 
instead occurs when the party responds to external pressures by juxtaposing new practices and ideas to the old ones.

The argument sketched out so far sheds light on the analytical benefits of approaching party change as a multidimensional phenomenon along three dimensions: adaptation, innovation and persistence (or lack of change). Somehow, this multidimensionality has been unduly neglected in empirical research, too exclusively focused on party adaptation. Our work contributes to filling this gap in the literature.

\section{The critical juncture in Italian party politics: the political turmoil of the} 1990s

This section highlights the key elements that define the Italian political turmoil of the 1990s as a critical juncture. We contend that two important defining features of a critical juncture are relevant in the Italian case: 1) inducing discontinuous and radical reorganization and 2) a breakdown of traditional and continuous dynamics. Since the structure, dynamics, format and organization of party politics in the past twenty years has undergone significant changes, some simplifying assumptions are necessary in order to carry out our analysis. The goal of this section is to briefly and schematically map out the fundamental traits of the Italian critical juncture. 
The first point to note is that while in most Western countries party deinstitutionalization has occurred incrementally (Chiaramonte and Emmanuele 2015), in Italy, by contrast, the historical parties suddenly and quickly departed from the political scene in the early 1990s. The arguments regarding the transformation of the Italian political system in the 1990s are well rehearsed and can be summarized as follows: new political supply, new political demand and new rules of the game. This abrupt renewal of the Italian political landscape represents a unique case study to test the expectations and predictions of the new wave of institutionalist theories based on critical juncture analysis.

Starting with the political supply, the departure of historical parties meant that the new millennium set off with new parties, fruit of a sequence of extinctions, new entries, split-offs and mergers that began in the early 1990s and continued for about two decades. That period represented year zero of a complex party readjustment process when the old party organizations, builders of the republican democracy born in the aftermath of WWII, broke down and disappeared (Ceccanti and Vassallo 2004, Cotta and Isernia 1996, Cotta and Verzichelli 2000, Di Virgilio 2002 and 2006, Grilli 2007, Ignazi 2008 and 2012, Newell 2009, Pasquino 2002). Moreover, modifications in the electoral law altered the format and mechanics of the party system, modifying the traditional competitive drives (Bellucci and Segatti 2010, Cotta and Verzichelli, 2016). 
It should be noted that the old party organizations were highly institutionalized and deeply anchored to civil society. This meant that historical parties were able to articulate demands and relationships between social partners and between party organizations and voters. They were able to aggregate long-term centreperiphery territorial divisions and profound cultural differences. Consequently, politically relevant cleavages were frozen into a highly structured party system (Morlino 1991; Pasquino 1986; Cotta and Verzichelli 2000; Vassallo 1992). The advent of a critical juncture initiated a 'revolution of the political supply' that swept away the old, highly institutionalized parties (Di Virgilio 2010).

Hence one salient trait of the critical juncture was to induce discontinuous and radical reorganization. The new parties were organizationally weaker than their predecessors, with looser ties to the national electorate and therefore with weaker political articulation capabilities. Several new terms were coined to describe such parties. They were either called 'personal parties', in the sense that they were put together by one person or the 'President party', if characterized by a charismatic leadership, such as Forza Italia (Calise 2011).

Furthermore, as predicted by the institutional theory of critical junctures the unprecedented collapse of historical parties caused a breakdown of traditional 
and continuous dynamics. In a few months the magistrates 'clean hands' policy put the old party leaders on trial for charges involving acts of political corruption and of improper and unlawful political financing methods (Burnett and Mantovani 1998). In consequence, the historical parties were depleted of those symbolic and material resources that had nurtured them for about half a century (Cotta and Isernia 1996). Such readjustment destroyed the Christian Democratic Party, which had been the dominant government party during the post-war period, and helped restyling its long-time political opponent, the Communist Party, into a centre-left party.

With the restructuring of political alternatives between the so-called First and Second Republic the strength of class cleavage dramatically decreased. Bellucci and Heath (2012) convincingly show that there was a sudden rupture in the relationship between both religion and vote and class and vote in 1994, with the transition to the Second Republic: 'since 1994 the level of class voting has fluctuated up and down, and in 2006 was only a little lower than levels observed in the First Republic, only to drop down again in the last election in 2008. However, the religious cleavage has remained at historically very low levels' $(2012,118)$. This quotation suggests that the new Italian political landscape brought about a breakdown of continuous dynamics, as predicted by critical juncture analysis. In 
turn, the breakdown of continuous dynamics created social and political fluidity that fuelled calls for renewal (Morlino and Tarchi 2006).

Such calls brought up new social cleavages, including ethical conservatism/progressivism (i.e. gay rights); winners vs. losers of globalization (i.e. immigration); materialism-post-materialism (i.e. environment) (Dalton and Welzel 2014, Hooghe, Marks and Wilson 2004, Hooghe et al. 2010, Inglehart 1990, Kriesi et al 2008). Against this background, we expect the attitudes and opinions of middle level elites of the new parties in the new millennium to reflect new social cleavages rather than mirror old cleavages.

To sum up, this section briefly highlighted the main traits of the critical juncture ushered in by the political cataclysm of the early 1990s. The critical juncture created a radically different political scenario in political supply, political demand and rules of the game that offered real and concrete opportunities for innovation. Interpreting the Italian political turmoil of the 1990s with the tools of critical juncture analysis raises the expectation that the decisions and choices of national party delegates are freer and thus there is more room for radical innovation.

\section{The unit of analysis and the dataset}




\section{1. The unit of analysis}

Building on Katz and Mair's (1983) theory of party organization, we explore party delegates' role of linkage coordination in three different 'faces' of party organization: the party on the ground, the party in central office and the party in public office. National delegates can be considered the party's representatives on the ground. In most cases, members vote for their representatives at the local/municipal level; these then elect the provincial/state's delegates who, in turn, elect the national delegates. For this reason middle level elites deeply affect the participatory linkage, which is the ability of a party to involve members in the decision making process (Lawson 1980, Merkl 2005, Bordandini 2013). Therefore, middle level elites are central actors of intra-party democracy because their activity allows the party on the ground, i.e. the party membership, to be involved in the formulation of its programme (Heidar and Saglie 2003). In addition, middle level elites may strengthen the party linkage with its political environment. This environmental linkage, or the capacity of parties to penetrate social groups, is what cleavage theorists generally refer to as 'segmentation' (Bellucci and Heath, 2012). Middle level elites engage in the segmentation capacity by connecting the party organization with interest groups, such as trade unions, and by participating in networks of cultural and recreational associations. In this manner middle level elites reinforce the cleavage structure in society and help 
anchoring the party on the ground with voters and sympathisers. National party delegates often enjoy social visibility thanks to their organizational or elective positions in politics and local level associations. They are focal members of party communities, moulding the relationship between top leadership, the party on the ground and society.

This role of linkage between parties and society has been progressively reinforced in recent years, chiefly because the party on the ground has significantly shrunk in size and relevance in the past twenty years. International trends demonstrate, with few exceptions, that party membership has declined substantially in most countries (van Biezen and Pogungtke 2014). Dropping membership figures mark the transition from the mass party to the catch-all party and then to the electoral professional party and finally to the cartel party (Katz and Mair 1995). This transition, which is characterized by party professionalization and new sources of party funding, altered the quality of party organizations (Bardi et al 2014). It strengthened the centralization process of the party organization, rendering more autonomous and powerful the party in central office and the party in public office.

Centralization of party organizations inevitably amplifies the role of middle level elites as linkage coordination. It is they, in fact, who must transmit the opinions 
and moods of members and supporters to the governing bodies and, at the same time, make the party's political line known at the local level (Ignazi 1989, 331). While recent trends in leadership selection indicate that party leaders are sometimes chosen from external arenas, such as Berlusconi in Italy, national party delegates have traditionally been the pool of leadership selection. More generally, a focus on party middle-level elites as unit of analysis is justified by the fact that party delegates are the leaders of the future or, in Schumpeterian terms, the "leaders-new people'4. These "leaders in the years to come" (Bordandini, Di Virgilio and Mulè 2011), mingle with top leadership while they build the bridge between the party membership and its leadership.

\subsection{The dataset}

National party delegates are activists with a long history of political militancy and, in many cases, with organisational or elected positions in politics at the local level. They are a unique 'strategic group' because they operate as a transmission belt within the vertical articulation of the party organization ${ }^{5}$. They perform roles of

\footnotetext{
${ }^{4}$ On this issue see Bordandini (2015).

${ }^{5}$ Party delegates have constituted a tested research field in the literature on political parties. The first comparative research of party delegates dates back to the seventies, namely the EPPMLE (European Political Parties Middle Level Elites) Project of the European Election Study, financed by the Volkswagen Foundation, the European Committee and the European Parliament. ${ }^{5}$ After the EPPMLE Project no other systematic research on national party delegates was carried out, except for sporadic surveys on the middle-level elites. Recently, however, a new and broader series of surveys of Italian middle-level party elites
} 
linkage-coordination between distinct organizational areas from which they derive the main resources to capitalize in the struggle for organizational power and, in general, in the quest for political influence" (Raniolo 2011, 236). They are 'individuals who are intensively involved politically, but who do not live off politics' (Bellucci, Maraffi and Segatti 2000, 16-17). National party delegates lie somewhere between local and national leadership, and thus can be defined as middle-level party elites.

Our data show that party delegates hold senior positions in both the party in central office and in public office. In our sample, $72 \%$ of national delegates hold leading positions in their party and about 1 out of ten hold elective office at the national level.

Middle-level elites are thus a "strategic group" not only because they are the driving force of party organization, but also because they connect the party on the ground, the party in central office and the party in public office. Party delegates can be considered privileged witnesses who experience from 'within' the parties' transformations induced from without. Hence, their values and attitudes are more stable compared to those of simple members, and this is

was conducted by the "Italian Observatory on the Transformations of Political Parties" which began organizing and carrying out the research project in 2004. ${ }^{5}$ 
another reason why they represent a bridge between the old and the new parties in Italy (Bordandini, Di Virgilio, Mulè, 2011).

Table 1. Party Delegates, 2004-2013. Number of respondents, sample and confidence intervals per party national convention

\begin{tabular}{|c|c|c|c|}
\hline & $\begin{array}{c}\text { Number of } \\
\text { Respondents }\end{array}$ & $\begin{array}{c}\text { Sample coverage } \\
\text { (\% of respondents on } \\
\text { delegates invited to the } \\
\text { convention) }\end{array}$ & $\begin{array}{c}\text { Confidence interval } \\
\text { (error margin of } \\
95 \% \text { ) }\end{array}$ \\
\hline Prc 2005 & 208 & 30.1 & 5.7 \\
\hline Pdci 2004 & 290 & 40.6 & 4.4 \\
\hline Verdi 2006 & 131 & 23.1 & 7.5 \\
\hline Ds 2005 & 434 & 27.5 & 4.0 \\
\hline Radicali 2008 & 173 & 48.5 & 5.4 \\
\hline Ds 2007 & 324 & 23.8 & 4.8 \\
\hline Sdi 2004 & 352 & 44.5 & 3.9 \\
\hline Pd 2009 & 205 & 20.6 & 6.1 \\
\hline PD 2013 & 352 & 35,2 & 4.2 \\
\hline $\begin{array}{l}\text { Margherita } \\
2007\end{array}$ & 305 & 16.5 & 5.1 \\
\hline $\begin{array}{l}\text { Margherita } \\
2004\end{array}$ & 310 & 22.1 & 4.9 \\
\hline $\begin{array}{l}\text { Nuovo PSI } \\
2005\end{array}$ & 206 & 13.7 & 6.3 \\
\hline Udeur 2005 & 96 & 8.0 & 9.6 \\
\hline Udc 2005 & 179 & 9.4 & 7.0 \\
\hline $\begin{array}{l}\text { Forza Italia } \\
2004\end{array}$ & 382 & 17.0 & 4.6 \\
\hline An 2009 & 143 & 9.5 & 7.8 \\
\hline La Destra 2008 & 284 & 9.5 & 5.1 \\
\hline Msft 2004 & 104 & 20.8 & 8.6 \\
\hline
\end{tabular}

Source: Calculated from Bordandini and Di Virgilio (2009-2013).

This paper draws upon data gathered from 4,478 interviews national party delegates at 18 national conventions (of 15 different parties) that took place 
between 2004 and 2013 (Table 1) . Data collection was carried out by means of a structured self-completion questionnaire distributed during the conventions (the sole exception was the Verdi [Greens] party, for which a postal survey was organised right after their national convention).

The questionnaire comprised a general section for all parties and a specific section adapted to the characteristics of each party and to the context in which the convention took place. It was not possible, unfortunately, to participate in the founding convention of PDL (Rome, March 27-29, 2009), due to the unanticipated decision of the party to deny, a few days before the beginning of the proceedings, the authorisation that had initially been granted ${ }^{7}$.

To summarize our expectations, following the 1990s critical juncture in Italian party politics we expect that the attitudes and opinions of middle-level elites reflect the transformations of political parties in the party belief system. Our work

\footnotetext{
${ }^{6}$ The national party delegates' research project until 2010 was part of an interuniversity research program (PRIN), co-funded by the Ministry of Education, University, and Research and the four universities involved: Florence (unit coordinated by Marco Tarchi, who was also the PRIN's national coordinator), Bologna (unit coordinated by Aldo Di Virgilio), Cosenza (unit coordinated by Francesco Raniolo), and Trieste (unit coordinated by Anna Bosco). The survey of 2013 was carried out by Paola Bordandini, Roberto Cartocci and Aldo Di Virgilio, Department of Political and Social Science (University of Bologna).

${ }^{7}$ The lack of data on Popolo delle Libertà (PDL) is mitigated by the fact that we have collected data for the two parties that merged in the PDL, namely, Forza Italia and Alleanza Nazionale. The Northen League did not hold national conventions in the period under scrutiny.
} 
assesses whether such transformations are the outcome of innovation, adaptation or persistence. In addition, we test whether high barriers to entry for women and young delegates might have dampened innovation since the sample shows that both women and young delegates are underrepresented $(23.3 \%$ and $21.5 \%$, respectively).

\section{The belief system of party delegates}

This section analyses the belief system of the Italian middle-level elite. In light of the early 1990s critical juncture, the expectation is that old attitudes and patterns are replaced by fresh attitudes and ideas. In the new scenario Italian middle-level elites could have developed policy priorities and programmes able to foster innovation.

Following previous empirical studies (Bordandini and Cartocci, 2011), we analyse delegates' belief system focusing on four groups of indicators. The first group relates to the political agenda as regards the most urgent reforms for the country: public administration and federal reforms, economic policy (taxes, tax evasion, inflation, labour market); welfare system (healthcare, education, immigration); environment (pollution); the judiciary (political corruption, crime and justice). The second group concerns ethical issues, such as abortion, assisted reproductive technology, drug liberalization, gay rights and so on. The third group pertains to traditional cleavages, including State/Church, Capital/Labour. Lastly, the fourth 
group is connected with trust in justice and in public order institutions. Our work improves on previous studies in two ways. First we apply these indicators to detect the presence of innovation, persistence and adaptation in the party delegates' belief system. Second, we simplify the data presented (Table 2) and add correlations (Table 3). This improvement helps identify the dimensions of adaptation, innovation and persistence.

Table 2. Less discriminant attitudes among party delegates. Eta squared $(<0.13)$ and percentages of 'very or fairly important'.

\begin{tabular}{lcc}
\hline $\begin{array}{l}\text { Below you will find a list of social, political, } \\
\text { economic issues. In your opinion, how }\end{array}$ & $\begin{array}{c}\text { in fairly important } \\
\text { problem' }\end{array}$ & \multirow{2}{*}{$\eta^{2}$} \\
\cline { 1 - 2 } important are each of these issues for Italy? & $\%$ & \\
\hline Immigration & 70.1 & 0.12 \\
Pollution & 91.8 & 0.12 \\
Inflation & 69.2 & 0.11 \\
Inefficiency of the PA & 84.0 & 0.10 \\
Political corruption & 78.6 & 0.09 \\
Tax evasion & 90.8 & 0.08 \\
Unemployment & 96.3 & 0.07 \\
Justice & 94.6 & 0.07 \\
Position of our country in Europe & 76.4 & 0.06 \\
Taxes & 78.7 & 0.06 \\
Backwardness of the Italian South & 89.6 & 0.06 \\
Education & 95.2 & 0.05 \\
Healthcare & 97.7 & 0.04 \\
Federal reform & 39.9 & 0.03 \\
\hline
\end{tabular}

Note: The data is weighted.

Source: Calculated from Bordandini and Di Virgilio (2009-2013)

Tables 2 and 3 compare those aspects in which the delegates differ to a lesser degree (Table 2), and those in which they differ to a greater extent (Table 3). Our 
statistical technique is the variance analysis. ${ }^{8}$ Table 2 shows that the most evenly distributed stances among the delegates, regardless of party affiliation, involve primarily the political agenda (the first group of indicators). Consistent with previous research, our results indicate that Italian middle-level elites agree, quite peculiarly, on the fact that all the problems are important for the country (see the low eta squared scores and the percentages of very-fairly important).

The delegates' profiles highlight a lack of priorities, linked to a widespread, nonproactive attitude of generalised indistinct criticism. Middle-level party officials are convinced of the need to found the entire country anew, from an economic, administrative, fiscal and socio-political point of view! Table 2 suggests that about eight out of ten respondents consider all these policy problems as 'very or fairly important'. One exception is federal reform, which is considered a priority by less than four delegates out of ten ${ }^{9}$.

\footnotetext{
${ }^{8}$ This technique determines which part of the variability of the respondents' answers is linked to a specific party identification and which, instead, is attributable to a general political cultural background.

${ }^{9}$ For a detailed and extended analysis of these data see Bordandini and Cartocci 2011.
} 
Table 3. Most discriminant opinions among party delegates (eta squared $>0.3$ ) and their correlation (when $r=>|0,4|$ ) with left-right wing (1-7) and catholic-non catholic dimension (1-0). Means, percentages of 'very or fairly agree', eta squared.

\begin{tabular}{|c|c|c|c|c|c|}
\hline \multirow{2}{*}{ Variables } & \multicolumn{3}{|c|}{$\begin{array}{l}\text { 'very or fairly } \\
\text { agree' }\end{array}$} & \multicolumn{2}{|c|}{ Correlation $(r=>|0,4|)$} \\
\hline & Mean & $\%$ & $\eta^{2}$ & $\begin{array}{l}\text { left-right } \\
\text { wing (1-7) }\end{array}$ & $\begin{array}{l}\text { Catholic-non } \\
\text { catholic (1-0) }\end{array}$ \\
\hline Index 'pro-immigration' (scale from 1 to 4 ) ${ }^{10}$ & 3.2 & - & 0.58 & -0.72 & -- \\
\hline $\begin{array}{l}\text { Legislation must guarantee equal rights for } \\
\text { homosexual couples (scale 1-4) }\end{array}$ & 2.6 & 54.5 & 0.54 & -0.63 & -0.48 \\
\hline $\begin{array}{l}\text { Substances commonly indicated as soft drugs } \\
\text { should be legalized (scale 1-4) }\end{array}$ & 2.4 & 46.4 & 0.49 & -0.60 & -0.51 \\
\hline $\begin{array}{l}\text { Capital must come before labour (scale from }-3 \text { to } \\
+3)^{11} \text {. }\end{array}$ & -0.3 & - & 0.43 & 0.53 & - \\
\hline Personal drug use must not be punished (scale 1-4) & 2.5 & 50.9 & 0.41 & -0.56 & -0.47 \\
\hline $\begin{array}{l}\text { Human embryo should be considered a "citizen" } \\
\text { with the same rights of his mother (scale 1-4) }\end{array}$ & 2.3 & 41.9 & 0.37 & 0.47 & 0.49 \\
\hline $\begin{array}{l}\text { Having an abortion must be made more difficult } \\
\text { (scale 1-4) }\end{array}$ & 1.5 & 31.2 & 0.35 & 0.51 & 0.41 \\
\hline Trust in the Judiciary (scale 1-4) & 2.4 & 49.8 & 0.34 & -0.45 & - \\
\hline Trust in the Catholic Church (scale 1-4) & 2.4 & 47.9 & 0.33 & - & 0.56 \\
\hline Index of trust in public order institutions (scale 1-4) & 2.8 & -- & 0.32 & - & -- \\
\hline
\end{tabular}

Note: The data is weighted.

10 We construct a pro-immigration index to analyse the greater or lesser support on the issue of immigration. The index varies from 1 (minimum support) to 4 (maximum support) and stems from the combination of the responses to the following queries (presented as a four-position Likert battery): a) Immigrants are a danger to our culture and to our identity; b) Immigrants, if they are regularly registered and if they pay their taxes, should be able to vote in the administrative elections of the municipality in which they live; c) Immigrants constitute a resource for economic development; d) Immigrants are a threat to public order and the security of people. We inverted the polarities of the queries a and $d$ and we carried out - in order to verify the congruency of the indicators - a single-factor confirmative analysis. The variance explained by the factor exceeds $70 \%$.

11 The values of the index vary from +3 (maximum trust in the association of entrepreneurs (Confindustria) compared to the trade union) to -3 (minimum trust in Confindustria compared to the trade union). 
Our results clearly point to a lack of innovation in the party delegates' belief system. The inability to set priorities indicates a rather void political agenda and no vision on which to build political projects and solutions. Such findings point to persistence rather than adaptation or innovation in the delegates' attitudes and opinions.

Table 3 illustrates the major differences among delegates by party affiliation (those that produce a square eta greater than 0.3 ). It reveals that there are four main differences: a) attitude towards immigration; b) ethical issues (namely, liberalisation of soft drugs, abortion, gay rights); c) capital/labour cleavage; d) trust in institutions, particularly in the Catholic Church and Judiciary.

The correlations reported in table 3 show that these new attitudes are strictly correlated with the traditional left-right dimension and the Catholic-non catholic cleavage. For this reason the new attitudes can be retraced to the old belief system, which is reflected in the left-right cleavage ${ }^{12}$. In terms of our theoretical framework, these findings also suggest the persistence of old and the emergence of new cleavages.

Openness towards immigrants is the most significant difference among delegates (Table 3).

${ }^{12}$ On this issue see Bordandini and Cartocci (2011). 
Table 4. Delegates' trust in institutions and attitudes on political issues. Mean values.

\begin{tabular}{|c|c|c|c|c|c|c|c|}
\hline & \multicolumn{2}{|c|}{$\begin{array}{c}\text { Trust in } \\
\text { institutions (scale } \\
1-4)\end{array}$} & \multicolumn{3}{|c|}{$\begin{array}{l}\text { Position on ethically oriented } \\
\text { issues (scale 1-4) }\end{array}$} & \multicolumn{2}{|c|}{$\begin{array}{l}\text { Position on two } \\
\text { indices: }\end{array}$} \\
\hline & $\begin{array}{c}\text { Churc } \\
h\end{array}$ & Judiciary & $\begin{array}{c}\text { Legalisatio } \\
\text { n of soft } \\
\text { drugs }\end{array}$ & $\begin{array}{l}\text { Equal rights } \\
\text { for same } \\
\text { sex couples }\end{array}$ & $\begin{array}{l}\text { More } \\
\text { difficult } \\
\text { to } \\
\text { abort }\end{array}$ & $\begin{array}{c}\text { pro- } \\
\text { immigration } \\
\text { (scale 1-4) }\end{array}$ & $\begin{array}{l}\text { Capital- } \\
\text { Labour } \\
\text { (scale } \\
+3 /-3 \text { ) }\end{array}$ \\
\hline Prc 2005 & 1.60 & 2.72 & 3.54 & 3.74 & 1.14 & 3.781 & -1.630 \\
\hline Pdci 2004 & 1.76 & 3.21 & 3.27 & 3.53 & 1.30 & 3.804 & -1.830 \\
\hline Verdi 2006 & 1.97 & 2.90 & 3.19 & 3.48 & 1.55 & 3.623 & -0.508 \\
\hline Ds 2005 & 2.21 & 3.11 & 3.08 & 3.48 & 1.33 & 3.776 & -0.835 \\
\hline Radicali 2008 & 1.37 & 2.02 & 3.88 & 3.82 & 1.13 & 3.624 & 0.171 \\
\hline Ds 2007 & 1.86 & 2.91 & 3.02 & 3.64 & 1.27 & 3.673 & -0.769 \\
\hline Sdi 2004 & 2.44 & 2.54 & 2.60 & 2.68 & 1.51 & 3.442 & -0.717 \\
\hline Pd 2009 & 2.29 & 3.05 & 2.62 & 3.20 & 1.60 & 3.656 & -0.372 \\
\hline $\begin{array}{l}\text { Margherita } \\
2007\end{array}$ & 2.93 & 2.79 & 2.00 & 2.49 & 2.29 & 3.393 & -0.141 \\
\hline $\begin{array}{l}\text { Margherita } \\
2004\end{array}$ & 3.12 & 3.03 & 2.02 & 1.98 & 2.35 & 3.502 & -0.475 \\
\hline $\begin{array}{l}\text { Nuovo Psi } \\
2005\end{array}$ & 2.37 & 1.73 & 2.13 & 2.26 & 1.79 & 3.018 & 0.051 \\
\hline Udeur 2005 & 3.09 & 2.34 & 1.83 & 1.97 & 2.41 & 3.125 & 0.122 \\
\hline Udc 2005 & 3.50 & 2.05 & 1.29 & 1.41 & 2.81 & 2.863 & 0.158 \\
\hline $\begin{array}{l}\text { Forza Italia } \\
2004\end{array}$ & 2.87 & 1.72 & 1.69 & 1.61 & 2.39 & 2.583 & 0.878 \\
\hline An 2009 & 2.83 & 1.80 & 1.23 & 1.69 & 2.92 & 2.456 & 0.430 \\
\hline $\begin{array}{l}\text { La Destra } \\
2008\end{array}$ & 2.65 & 1.75 & 1.32 & 1.46 & 2.85 & 2.110 & 0.332 \\
\hline Msft 2004 & 2.26 & 1.73 & 1.33 & 1.29 & 2.92 & 1.818 & -0.021 \\
\hline
\end{tabular}

Source: Calculated from Bordandini and Di Virgilio (2009-2013)

We now focus on the differences in responses of delegates belonging to different political parties, along the dimensions of adaptation, innovation and persistence.

Table 4 shows that differences in responses are quite predictable on the basis of 
party positions on old cleavages. This finding strongly suggests persistence in the differences among parties rather than innovation.

The data illustrate, for instance, that $\mathrm{PdCl}$ delegates record the highest score in the 'pro-immigration' index (mean value of 3.8); conversely, the lowest value is found among MSFT respondents (mean value of 1.9) The mean values clearly distinguish left wing from right wing parties, even if the trend is not monotonic.

By contrast, a clear monotonic trend from left to right is found in the liberalisation of soft drugs, gay rights, the protection of the embryo in vitro under general human rights, abortion, and the death penalty. This says that with regard to ethical issues the mean value drops (soft drugs and gay rights) or rises (more difficult recourse to abortion) moving from left to right.

As expected, Table 4 also reports that trust in the Church peaks among delegates of Catholic parties. Apart from this, confidence in church presents a monotonic evolution, with lower values found in left-wing parties, compared to those of the right.

No different is the evolution of the traditional cleavage capital/labour. Our findings reveal the negative attitude of left-wing party delegates towards Confindustria, the Italian association of employers and the positive attitude of those who belong to Forza Italia (mean of 0.9), AN (0.4) and La Destra (0.3). The cleavage capital/labour, therefore, fully reflects the persistence of traditional alignments. 
To conclude, close examination of delegates' attitudes suggests that the new cleavages are simply added to the old ones, without breaking the past patterns typical of Italian politics. The correlations in table 3 show that the fault lines are the old ones: catholics/non catholics and Left/Right. Rather than innovation in the delegates' belief system, the data suggest a crystallization where new fault lines are added to the old ones without replacing them. ${ }^{13}$ Therefore we cannot speak of Schumpeterian innovation that 'breaks old tradition and creates new ones'. Perhaps for this reason, experts of Italian politics have recently highlighted 'the miserable plight of all Italian political parties and their poverty of ideas and projects' (Pasquino and Valbruzzi 2012, 620). This persistence of old patterns requires explanation. It is likely that such crystallisation of the belief system has played an important role in hindering innovation and/or the emergence of innovative political entrepreneurs.

${ }^{13}$ These results are consistent with Cartocci (2011). 


\section{Entry barriers and 'negative case'}

\subsection{Entry barriers}

In view of the political fluidity generated by the critical juncture of the early 1990 s, we expect new opportunities for young people and women. Historical accounts of internal party conflicts demonstrate that new generations of leaders often elaborate innovative programmes that challenge the dominant coalition (Panebianco, 1988). And it is women, traditionally under-represented in political parties, who can bring about different visions for problem solving decisions.

We know from previous research that women have been significantly underrepresented among Italian national party delegates and that, in general, the average age of party delegates has been stable for the past thirty years (Mulé 2011).

We build and improve on those findings to examine whether there is a gender and age imbalance in the delegates' attitudes towards new social cleavages. Our data show that women are more open to immigration $(86 \%$ of women against $79 \%$ of men), gay rights ( $73 \%$ against $53 \%)$, the legalization of soft drugs $(57 \%$ against $47 \%$ ) and abortion (82\% against $67 \%$ ). Furthermore, women are more favourable to in vitro fertilization, only $30 \%$ believe the human embryo is an unborn citizen against $45 \%$ of men. Finally, women are more concerned about the environmental impact of generating nuclear power, only $14 \%$ are in favour of 
nuclear power against $25 \%$ of men. Likewise, young delegates (under 36 years old), are more open to gay rights (65\% against $55 \%$ over 36 years old), to the legalization of soft drugs (56\% against $47 \%$ ) and to the environment (18\% accept nuclear power against $24 \%$ ). Our data clearly illustrate that there is a gender and age imbalance in the delegates' attitudes towards new social cleavages.

\subsection{Italy as a 'negative case'}

Section 5 established that the variability of delegates' attitudes towards new social cleavages was integrated into the traditional left-right and catholic-noncatholic cleavages. To assess whether women and young delegates contribute to party innovation strategies aside these traditional cleavages, we run two regression models (Table 5). The first one regresses each new cleavage on leftright and catholic- non catholic variables; in the second model regressors are augmented with age (dummy: $0=$ under 36 ) and gender (female $=0$ ). This second model allows us to estimate the age and gender influence on the party's openness to new cleavages irrespective of left-right and catholic-non catholic dimensions. Table 5 confirms the relevance of left-right and catholic-non catholic variables to explain the variability of new cleavages as underlined in section 6 . However, Models 2 suggests the relevance of age and gender beyond traditional cleavages. 
Regression coefficients reported are almost always significant. Their signs suggest that women are more open to innovation (in terms of new cleavages) than men and young delegates are more open to innovation than older delegates. In general, gender's standardized coefficients are greater in absolute values than age's standardized coefficient. Importantly, R squared increases from the first to the second model for each dependent variable.

Table 5. Multivariate regressions predicting openness towards immigrants, rights for homosexual couples, drug liberalisation and closeness toward abortion. Two models compared.

\begin{tabular}{|c|c|c|c|c|c|c|c|c|c|c|c|c|}
\hline & \multicolumn{6}{|c|}{ Index 'pro-immigration' (scale 1-4) } & \multicolumn{6}{|c|}{ Equal rights for same sex couples (scale 1-4) } \\
\hline & \multicolumn{3}{|c|}{ Model 1} & \multicolumn{3}{|c|}{ Model 2} & \multicolumn{3}{|c|}{ Model 1} & \multicolumn{3}{|c|}{ Model 2} \\
\hline & B & SE B & Beta & B & SE B & Beta & B & SE B & Beta & B & SE B & Beta \\
\hline$\overline{\text { Age }}$ & & & & $-0.002^{* *}$ & 0.001 & -0.026 & & & & $-0,291$ & 0.038 & -0.099 \\
\hline $\begin{array}{l}\text { Gender } \\
\text { (0 female) }\end{array}$ & & & & $-0.069^{*}$ & 0.021 & -0.039 & & & & $-0,359$ & 0.036 & $-0,127$ \\
\hline $\begin{array}{l}\text { Catholic-non } \\
\text { catholic } \\
(1-0)\end{array}$ & $-0.071^{*}$ & 0.022 & -0.044 & $-0.0066^{*}$ & 0.022 & -0.041 & $-0,626$ & 0.038 & $-0,238$ & $-0,604$ & 0.037 & $-0,230$ \\
\hline $\begin{array}{l}\text { Left-right } \\
(1-7)\end{array}$ & -0.363 & 0.007 & -0.0695 & -0.362 & 0.007 & -0.693 & -0.432 & 0.012 & -0.513 & -0.424 & 0.012 & -0.504 \\
\hline Cous & 4.529 & 0.023 & - & 4.512 & 0.051 & - & 4.482 & 0.040 & - & 5.241 & 0.081 & - \\
\hline R2 & & 0.511 & & & 0.515 & & & 0.427 & & & 0.453 & \\
\hline (N) & & (3408) & & & (3376) & & & (3432) & & & (3376) & \\
\hline
\end{tabular}




\begin{tabular}{|c|c|c|c|c|c|c|c|c|c|c|c|c|}
\hline & \multicolumn{6}{|c|}{ Legalisation of soft drugs (scale 1-4) } & \multicolumn{6}{|c|}{ More difficult to abort (scale 1-4) } \\
\hline & \multicolumn{3}{|c|}{ Model 1} & \multicolumn{3}{|c|}{ Model 2} & \multicolumn{3}{|c|}{ Model 1} & \multicolumn{3}{|c|}{ Model 2} \\
\hline & $\mathrm{B}$ & B & B & B & SE B & Beta & $\mathrm{B}$ & SE B & Beta & $B$ & SE B & Beta \\
\hline Age & & & & -0.232 & 0.038 & -0.081 & & & & (ns) & (ns) & (ns) \\
\hline $\begin{array}{l}\text { Gender } \\
\text { (0 female) }\end{array}$ & & & & $-0.063^{\star * *}$ & 0.037 & -0.023 & & & & 0.274 & 0.037 & 0.107 \\
\hline $\begin{array}{l}\text { Catholic-non } \\
\text { catholic } \\
(1-0)\end{array}$ & -0.752 & 0.037 & $-0,752$ & -0.736 & 0.037 & -0.288 & 0,527 & 0.038 & 0,222 & 0.522 & 0.038 & 0.220 \\
\hline $\begin{array}{l}\text { Left-right wing } \\
(1-7)\end{array}$ & -0.366 & 0.012 & -0.448 & -0.367 & 0.012 & -0.450 & 0.306 & 0.012 & 0.402 & 0.300 & 0.012 & 0.394 \\
\hline Constant & 4.101 & 0.040 & - & 4,560 & 0.082 & - & 0.548 & 0.041 & - & $0.278^{*}$ & 0.083 & - \\
\hline $\mathrm{R} 2$ & & 0.403 & & & 0.410 & & & 0.289 & & & 0.303 & \\
\hline (N) & & (3441) & & & $(3386)$ & & & (3372). & & & (3319) & \\
\hline
\end{tabular}

\begin{tabular}{|c|c|c|c|c|c|c|c|c|c|c|c|c|}
\hline & \multicolumn{6}{|c|}{$\begin{array}{l}\text { Human embryo should be considered a "citizen" } \\
\text { with the same rights of the mother (scale 1-4) }\end{array}$} & \multicolumn{6}{|c|}{$\begin{array}{l}\text { Energy problems are solved only with nuclear } \\
\text { power irrespective of its environmental effects } \\
\text { (scale 1-4) }\end{array}$} \\
\hline & \multicolumn{3}{|c|}{ Model 1} & \multicolumn{3}{|c|}{ Model 2} & \multicolumn{3}{|c|}{ Model 1} & \multicolumn{3}{|c|}{ Model 2} \\
\hline & $B$ & $B$ & $B$ & $B$ & SE B & Beta & $B$ & SE B & Beta & $B$ & SE B & Beta \\
\hline Age & & & & (ns) & (ns) & (ns) & & & & $0.121^{*}$ & 0.036 & 0.121 \\
\hline $\begin{array}{l}\text { Gender } \\
\text { (0 female) }\end{array}$ & & & & 0.215 & 0.043 & 0.079 & & & & 0.252 & 0.035 & 0.252 \\
\hline $\begin{array}{l}\text { Catholic-non } \\
\text { catholic } \\
\text { (1-0) }\end{array}$ & 0.896 & 0.045 & 0.343 & 0.887 & 0.045 & 0.339 & 0.191 & 0.036 & 0.092 & 0.180 & 0.036 & 0.087 \\
\hline $\begin{array}{l}\text { Left-right wing } \\
(1-7)\end{array}$ & 0.261 & 0.014 & 0.325 & 0.255 & 0.014 & 0.316 & 0.246 & 0.011 & 0.370 & 0.240 & 0.011 & 0.362 \\
\hline Constant & 0.770 & 0.048 & & 0.568 & 0.097 & & 0.907 & 0.038 & & 0.522 & 0.078 & \\
\hline R2 & & 0.318 & & & 0.322 & & & 0.175 & & & 0.192 & \\
\hline (N) & & $(2872)$ & & & $(2829)$ & & & $(3440)$ & & & $\begin{array}{l}(3383) \\
\end{array}$ & \\
\hline
\end{tabular}

Note: $p<0.001{ }^{*} p<0.01{ }^{* *} p<.005$ (ns)=not significant

Source: Calculated from Bordandini, Cartocci and Di Virgilio's dataset

Regression results suggest that high barriers to entry in Italian party organizations help explain the limited innovative capability of party delegates.

Overall, the low generational turnover indicates a telling myopic behaviour, which protects the status quo rather than investing in the future. Entry barriers in Italian 
political parties seem to be surprisingly high in the new millennium despite the critical juncture of the early 1990s.

In critical juncture analysis Italy is a 'negative' case. Negative cases occur when institutional change was possible but did not happen (Capoccia, 2015). In the first decade of the new millennium, party leaders failed to appreciate the important innovative role of young people and women.

\section{Looking forward: searching for innovation}

This section updates our work by analysing the responses of delegates at the recent national party conference of the Partito Democratico (PD) held in Milan in 2013, which elected Matteo Renzi to the head of the party (352 cases). The PD is one of the few Italian political parties that has maintained a relatively strong party organization. For this reason, the PD is an important case study because national delegates retain their role of transmission belt in the party organization chain. This new dataset is a useful testing ground to assess the association between innovation and age and gender.

As a consequence of his election at the head of the PD, Matteo Renzi replaced Enrico Letta as Italian prime minister in February 2014. One innovative policy in terms of belief system introduced by the Renzi government was to legalize same-

sex civil unions (Law n.76/ 2016). This is the reason why in this section we focus 
on the PD delegates' attitudes on gay rights in 2013. In general the data show that young delegates are more innovative than older ones $(95.8 \%$ young are progay rights against $91.6 \%$ of older ones). Likewise, women (95.3\%) are more innovative than men $(89.3 \%)$.

Applying our two regression models (explained in the previous section) to the new dataset of 2013, we test if and how age and gender influence the dependent variable (pro-gay rights), controlled for left/right and catholic/non-catholic.

Table 6. Multivariate regressions predicting openness towards rights for homosexual in 2013's PD delegates. Two models compared.

\begin{tabular}{|c|c|c|c|c|c|c|}
\hline & Equal ri & ights for $\mathrm{s}$ & sex coupl & s (scale 1 & & \\
\hline & Model 1 & & & Model 2 & & \\
\hline & $\mathrm{B}$ & SE & Beta & $B$ & SE & Beta \\
\hline$\overline{\mathrm{Age}}$ & & & & $-0,006^{* *}$ & $0,003^{* *}$ & $-0,115^{\star *}$ \\
\hline $\begin{array}{l}\text { Gender } \\
\text { (0 female) }\end{array}$ & & & & $-0,187^{* *}$ & $0,071^{* *}$ & $-0,138^{\star *}$ \\
\hline Catholic-nor & & & & & & \\
\hline $\begin{array}{l}\text { catholic } \\
(1-0)\end{array}$ & $\overline{0}, 237^{* *}$ & $0,082^{* *}$ & $-0,159^{* *}$ & $-0,239 * *$ & $0,079^{* *}$ & $-0,166^{\star *}$ \\
\hline $\begin{array}{l}\text { Left-right } \\
(1-7)\end{array}$ & $-0,418$ & 0,072 & $-0,318$ & $-0,375$ & 0,070 & $-0,293$ \\
\hline Constant & 4,816 & 0,182 & & 5,092 & 0,213 & \\
\hline $\mathrm{R} 2$ & 0,161 & & & 0,187 & & \\
\hline$(\mathrm{N})$ & 318 & & & 318 & & \\
\hline
\end{tabular}

It should be noted that our models fit well the PD case because it is internally divided into a centre-left/left wing and a catholic/non-catholic wing (Pasquino and Venturino 2014). 
Table 6 shows that $R$ squared increases when passing from the first to the second model (augmented with age and gender as regressors). Our findings confirm that coefficients are significant. Model 2 supports our hypothesis that women are more open to innovation than men and young delegates more than older ones.

\section{Conclusions}

The article offered a fresh analytical perspective in the literature on party politics by weaving insights from recent theories of institutional change based on critical juncture analysis. It argued that party change is not simply adaptation to environmental pressures, as conventional wisdom suggests. Rather, party change is a multidimensional process characterised by adaptation, innovation and persistence. Unpacking the concept of party change in these three dimensions shed light on what occurred to the belief system of a 'strategic group' of Italian party organizations. Empirically, the article attained new results by exploring these dimensions in the national party delegates' belief system. Our results clearly point to a lack of innovation in the policy agenda. Most importantly, the differences among parties are related to ethical issues, which reflect adaptation to old cleavages.

Our findings, however, are inconsistent with critical juncture analysis that predicts innovation. In particular, our results highlight the enduring persistence of old 
cleavages and the consequent lack of innovation in the attitudes and opinions of party delegates in the new millennium.

To explain these findings we tested the hypothesis that innovation is a function of lower barriers to entry in party politics. The results show that women and young people are more open to innovative trends, such as new social cleavages. Hence barriers to entry in party organizations appear to be a key to understanding the lack of innovation in middle-level elites' attitudes and opinions. The important question regarding what other conditions provide incentives for innovation in the belief system of middle-level elites calls for further scholarly research. 


\section{References}

Appleton, Andrew M., and Daniel S. Ward. 1997. Party Response to Environmental Change: A Model of Organizational Innovation. Party Politics 3 (3): $341-6$

Bardi, Luciano, and Enrico Calossi. 2009. 'Model of Part Organization and Europarties'. In Activating the Citizen. Dilemmas of Participation in Europe and Canada, edited by Joan DeBrdeleben and Jon H. Pammett. Chippenham and Eastbourne: Palgrave MacMillan.

Bardi, Luciano, Stefano Bartolini, and Alexander Trechsel. 2014. 'Party adaptation and organizational change.' Party Politics, Special Issue, 20 (2).

Stefano Bartolini and D'Alimonte, Roberto, eds. 2002. Maggioritario finalmente? La transizione elettorale 1994-2001. Bologna, II Mulino.

Bellucci, Paolo and Oliver Heath. 2012. The Structure of Party-Organization Linkages and the Electoral Strength of Cleavages in Italy, 1963-2008. British Journal of Political Science 42 (1): 107-135.

Bellucci, Paolo, Marco Maraffi and Paolo Segatti. 2000. PCI, PDS, DS. La trasformazione dell'identità politica della sinistra di governo. Roma, Donzelli.

Bellucci, Paolo and Paolo Segatti, eds. 2010. Votare in Italia: 1968-2008. Dall'appartenenza alla scelta. Bologna: II Mulino.

Ingrid, van Biezen and, Thomas Poguntke, 2014. 'The Decline of Membershipbased Politics'. Party Politics 20 (2), 205-216

Billari, Francesco C. 2007. 'Il blocco generazionale della politica italiana.' II Mulino (5): 795-804.

Bordandini, Paola. 2013. 'Renewal, and Tradition: Comparing Italian Radical Left Parties through their Middle-Level Elites.' South European Society \& Politics 18(1): 61-79.

Bordandini, Paola. 2015. 'National Party Delegates'. IPS - Italian Political Science $10(1)$. 
Bordandini, Paola. 2015. 'La fiducia in Italia'. In L'Italia e le sue regioni (IV vol. Società) edited by Mariuccia Salvati, and Loredana Sciolla, 79-92. Roma: Istituto della Enciclopedia Italiana Fondata da G. Treccani.

Bordandini, Paola, and Roberto Cartocci. 2011. 'La cultura politica dei delegati nazionali di partito'. Polis XXV(2): 171-204.

Bordandini, Paola, and Aldo Di Virgilio. 2009-2013. I partiti italiani a congresso. Ricerche sui delegati (book series). Bologna: Clueb.

Bordandini, Paola, Aldo, Di Virgilio and Rosa, Mulè, eds. 2011. 'I delegati congressuali di partito'. Special issue. Polis XXV(2).

Bosco, Anna, and Leonardo Morlino, eds. 2006. 'Party Change in Southern Europe.' South European Society \& Politics 11(3-4).

Burnett, Stanton H., and Luca Mantovani. 1998. The Italian Guillotine. Operation Clean Hands, and the Overthrow of Italy's First Republic. Lanham: Rowman \& Littlefield.

Calise, Mauro. 2010. Il Partito personale. I due corpi del leader. Bari-Roma: Laterza.

Capoccia, Giovanni 2015, 'Critical Junctures and Institutional Change'. in Advances in Comparative -Historical Analysis, edited by Mahoney, James and Kathleen Thelen, 147-179. Cambridge: Cambridge University Press.

Cartocci Roberto. 2011. 'Political Culture'. In International Encyclopedia of Political Science edited by Bertrand Badie, Dirk. Berg-Schlosser \& Leonardo Morlino, 1968-1980. London: Sage.

Ceccanti, Stefano, and Salvarore Vassallo, eds. 2004. Come chiudere la transazione, Cambiamento, apprendimento e adattamento nel sistema politico italiano. Bologna: II Mulino.

Chiaramonte, Alessandro, and Vincenzo Emanuele. 2015. 'Party System Volatility, Regeneration, and De-Institutionalization in Western Europe (19452015).' Party Politics, Online First: 1-13, DOI:10.1177/1354068815601330.

Cotta, Maurizio, and Pierangelo Isernia, eds. 1996. II gigante dai piedi d'argilla. Bologna: il Mulino. 
Cotta, Maurizio, and Luca Verzichelli. 2000. 'From constrained coalitions to alternating governments?'. In Coalition Governments in Western Europe edited by Wolfgang C. Müller \& Kaare Strøm, 433-497. Cambridge: Cambridge University Press.

Cotta, Maurizio, and Luca Verzichelli. 2016. II Sistema Politico Italiano. Third Edition. Bologna: II Mulino.

D'Alimonte, Roberto, and Alessandro Chiaramonte, eds. 2007. Proporzionale ma non solo. Le elezioni politiche del 2006. Bologna: II Mulino.

D'Alimonte, Roberto, and Alessandro Chiaramonte, eds. 2010. Proporzionale se vi pare. Le lezioni politiche del 2008. Bologna: II Mulino.

Di Virgilio, Aldo. 2002. 'L'offerta elettorale. La politica delle alleanze si istituzionalizza?'. In Maggioritario finalmente? La transizione elettorale 19942001 edited by Roberto D'Alimonte, and Stefano Bartolini, 79-129.

Di Virgilio, Aldo. 2006. 'Dal cambiamento dei partiti all'evoluzione del sistema partitico'. In Partiti e caso italiano edited by Leonardo Morlino, and Marco Tarchi, 173-206.

Di Virgilio, Aldo. 2010. 'Nuovi partiti e nuove regole di voto in Italia: la rivoluzione dell'offerta'. In La politica e le radici editded by Carlo Baccetti, Silvia Bolgherini, Renato D'Amico, and Gianni Riccamboni, 151-174. Novara: Liviana.

Di Virgilio Aldo and Daniela Giannetti, 2011. I nuovi partiti italiani e la selezione dei candidati: gli orientamenti dei delegati congressuali'. Polis 25 (2): 205-234.

Dalton, Russell J, David M. Farrell, and lan McAllister. 2011. Political Parties, and Democratic Linkage: How Parties Organize Democracy. Oxford: Oxford University Press.

Dalton, Russell, and Christian Welzel, eds. 2014. The Civic Culture Transformed: From Allegiant to Assertive Citizens. Cambridge: Cambridge University Press.

Donatella, Della Porta and Mario Diani. 1997. I movimenti sociali. Rome: La Nuova Italia Scientifica.

Franzmann, Simon T. 2011. 'Competition, contest, and cooperation: The analytic framework of the issue market.' Journal of Theoretical Politics 23(3): 317-343. 
Grilli di Cortona Pietro. 2007. Il cambiamento politico in Italia. Dalla Prima alla Seconda Repubblica Roma: Carocci.

Harmel, Robert, and Kenneth Janda. 1994. 'An integrated theory of party goals, and party change.' Journal of Theoritical Politics 6(3): 259-287.

Heidar, Knut and Jo Saglie. 2003. A decline of linkage? Intra-party participation in Norway, 1991-2000. European Journal of Political Research 42 (6): 761-78.

Hooghe, Liesbet, Gary Marks and Carole J. Wilson. 2002. Does Left/Right Structure Party Positions on European Integration?. Comparative Political Studies 35 (8): 965-989.

Hooghe, Liesbet, Ryan Bakker, Anna Brigevich, Catherine de Vries, Erica Edwards, Gary Marks,Jan Rovny, Marco Steenbergen and Milada Vachudova. 2010. Reliability and Validity of Measuring Party Positions: The Chapel Hill Expert Surveys of 2002 and 2006. European Journal of Political Research 49 (4): $687-$ 703.

Ignazi, Piero. 2012. Forza senza legittimità. Il vicolo cieco dei partiti. Bari: Laterza.

Ignazi, Piero. 2008. Partiti politici in Italia. Bologna: II Mulino.

Ignazi, Piero, Ugo Mancini, and Gianfranco Pasquino. 1981. 'Omogeneità e diversità nei quadri intermedi (Dc, Msi, Pdup, PSDI).' Biblioteca della Libertà XVII(79): 201-251.

Inglehart, Ronald. 1990. 'Culture Shift in Advanced Industrial Society'. Princeton: Princeton.

Katz, Richard S., and Peter Mair, eds. 1992. Party Organizations. A Data Handbook. London: Sage.

Katz, Richard S., and Peter Mair. 1995. 'Changing Models of Party Organization, and Party Democracy: The Emergence of the Cartel Party.' Party Politics 1(1): 128.

Kitschelt, Herbert. 1989. The Logic of Party Formation. Ithaca, New York: Cornell University Press. 
Kriesi, Hanspeter, Edgar Grande, Romain Lachat, Martin Dolezal, Simon Bornschier and Timotheos Frey. 2008. West European Politics in the Age of Globalization. Cambridge: Cambridge. University Press.

Krooks, Mona L., and Sarah Childs, eds. 2010. Women, gender, and politics: a Reader. Oxford: Oxford University Press.

Lanzara, Giovan Francesco. 2016. Shifting Practices. Reflections on Technology, Practice, and Innovation. Cambridge: The MIT Press.

Lawson, Kay .1980. 'Political Parties, and Linkage'. In Political Parties, and Linkage: A Comparative Perspective edited by K. Lawson. New Haven: Yale University Press.

Lowi, Theodore. 1963. 'Toward Functionalism in Political Science: The Case of Innovation in Party Systems,' American Political Science Review, 57: 570-592.

Lusoli, Wainer, and Stephen Ward (2004). 'Digital Rank-and-File: Party Activists' Perceptions and Use of the Internet.' British Journal of Politics and International Relations, 6(4), 473-450.

Mahoney, James, and Kathleen Thelen, eds, 2015. Advances in Comparative Historical Analysis. Cambridge: Cambridge University Press.

Mair, Peter. 1997. Party System Change: Approaches, and Interpretations. Oxford: Oxford University Press.

Mair, Peter. 2006. 'Party System Change'. In Handbook of Party Politics edited by Richard S. Katz and William J, 63-73. Crotty. London: Sage.

Margetts, Helen .2006. 'Cyber Parties?'. In Handbook of Party Politics edited by Richard S. Katz and William Crotty, 528-535. London: Sage.

McDonnell, Duncan, and Marco Valbruzzi. 2013. 'Defining, and Classifying Technocrat-led, and Technocratic Government'. Paper presented at the panel Technocrats, Caretakers, and Parties in the Long European Crisis European Union Studies Association Conference, Baltimore, May 9-11.

Merkl, Peter H. 2005. 'Linkage, or What Else? The Place of Linkage Theory in the Study of Political Parties'. In Political Parties, and Political Systems: the 
Concept of Linkage Revisited edited by Andrea Römmele, David M. Farrell, and Piero Ignazi Praeger: Westport (CT).

Morlino, Leonardo and Marco Tarchi, eds. 2006. Partiti e caso italiano. Bologna: II Mulino.

Mulé, Rosa. 2011. Delegati congressuali: cos'è cambiato dopo trent'anni. Polis XXV(2): 263-286.

Newell, James L. 2009. 'The man who never was? The Italian transition, and 2008 election.' Journal of Modern Italian Studies, 14(4): 395-412.

Newton, Kenneth, and Pippa Norris. 2000. 'Confidence in Public Institutions: Faith, Culture or Performance?'. In Disaffected Democracies: What's Troubling the Trilateral Countries? Edited by Susan J. Pharr \& Robert D. Putnam. Princeton: Princeton University Press.

Niedermayer, Oscar. 1986. 'Methodological and practical problems of comparative party elites research: the EPPMLE project.' European journal of political research, 1-2: 253-258.

Panebianco, Angelo. 1988. Political Parties: Organization, and Power. Cambridge: Cambridge University press.

Pasquino, Gianfranco, eds. 2002. Dall'Ulivo al governo Berlusconi. Bologna: II Mulino.

Pasquino Gianfranco and Fulvio Venturino, eds. 2014 /I Partito Democratico secondo Matteo. Bologna: BUP.

Pasquino, Gianfranco, and Marco Valbruzzi. 2012. 'Non partisan governments Italian-style: decisionmaking, and accountability.' Journal of Modern Italian Studies 17(5): 612-629.

Lowi, Theodore. 1963. 'Toward Functionalism in Political Science: The Case of Innovation in Party Systems.' American Political Science Review 57(3): 570-583.

Ramella, Francesco. 2013. Sociologia dellinnovazione economica. Bologna: II Mulino.

Raniolo, Francesco. 2002. La partecipazione politica. Bologna: II Mulino. 
Raniolo, Francesco, eds, 2004. Le trasformazioni dei partiti politici. Soveria Mannelli: Rubbettino.

Raniolo, Francesco. 2011. 'Partecipazione e partiti. la prospettiva dei delegati congressuali'. Polis XXV(2): 235-262.

Raniolo, Francesco. 2013. I partiti politici. Roma-Bari: Laterza.

Rohrschneider, Robert. 1994. 'How iron is the iron law of oligarchy? Robert Michels and national party delegates in eleven west European democracies'. European journal of political research 2: 207-238.

Scarrow, Susan E. 2000. 'Parties Without Members? Party Organization in a Changing Electoral Environment'. In Parties Without Partisans: Political Change in Advanced Industrial Democracies edited by Russell J. Dalton and Martin P. Wattenberg, 79-101. Oxford: Oxford University Press.

Schumpeter, Joseph A. 1934. The Theory of Economic Development. Cambridge (Mass): Harvard University Press.

Schumpeter, Joseph A. 1939. Business Cycles: A Theoretical, Historical, and Statistical Analysis of the Capitalist Process, 2 vol. New York: Mcgraw-Hill.

Tronconi, Filippo, ed. 2015. Beppe Grillo's Five Star Movement. Farnham: Ashgate.

Vaccari, Cristian. 2012. 'Online Participation in Italy: Contextual Influences, and Political Opportunities'. In Comparing Digital Politics: Digital Media, and Political Engagement Around the World, edited by Eva Anduiza Perea, Michael James Jensen and Laia Jorba, 138-159. Cambridge: Cambridge University Press.

Ventura, Sofia. 2013. 'Leaders, and Parties After the Italian Elections.' Contemporary Italian Politics 5(2): 179-195.

von Beyme, Klaus.1985. Political Parties in Western Democracies. New York: St. Martin's Press.

Ware, Alan. 1996. Political Parties and Party Systems. Oxford: Oxford Univ. Press. 